\title{
The Wrocław urban planning from general plans to studies on land use planning
}

\author{
Robert Masztalski \\ robert.masztalski@pwr.edu.pl \\ Piotr Kryczka \\ piotr.kryczka@pwr.edu.pl \\ Department of Urban Design and Settlement Processes, \\ Faculty of Architecture, Wroclaw University of Science and Technology
}

\begin{abstract}
The purpose of this paper is to diagnose the degree of change of selected elements of functional and spatial structure of Wrocław. This is a review of the Wrocław urban planning at the turn of the $20^{\text {th }}$ and $21^{\text {st }}$ century. The plans of transport system, the issues of natural environment, recreation and leisure and the proposed arrangements and systems of services provided to residents were analysed. These elements were compared with national legislative processes and general tendencies in urban planning.
\end{abstract}

Keywords: planning documents, history of spatial planning, spatial policy, Wrocław

\section{Introduction}

The theory and practice of spatial planning in Poland at the turn of the $20^{\text {th }}$ and $21^{\text {st }}$ century have evolved along with numerous legislative changes affecting the way of perceiving and implementing spatial policy, both in the aspect of processes governing spatial development and in social terms. The normalization of socio-economic mechanisms in geographical space is considered to be the basic element of shaping spatial policy, while political and economic situation was, and still is, reflected in how the rules behind the planning and building development are adapted to the existing systemic conditions. Moreover, the process of legislative changes in Poland, at that time, was accompanied by the process of political and economic transformation of the country towards political pluralism and economic freedom.

The purpose of this paper is to diagnose the phenomenon of changes in the Wrocław urban planning from the end of the $20^{\text {th }}$ century to the present at the background of settlement processes initiated in the first half of the $20^{\text {th }}$ century. The analysis is based on guidelines from planning documents, in particular local spatial development plans adopted at the end of the $20^{\text {th }}$ century and studies on land use planning adopted after 1994. Reference was made to the principles of shaping spatial policy contained in laws directly related to planning and spatial development, and in force during the research period. Particular emphasis was put on the analysis of the dynamics of changes in three main elements of functional and spatial structure related to the shaping of spatial policy of Wrocław in planning documents, i.e.:

transport system and mobility policy,

- the natural environment, recreation and leisure,

nierarchical arrangement of service centres and service systems.

The purpose of the above analysis is to establish the degree of continuity of settlement processes in local dimension and to assess the validity and effectiveness of legislative changes related to urban planning and spatial planning at the national level. 


\section{Historical conditions}

Rapid twentieth-century industrialisation contributed to a significant increase in the number of city dwellers in the world. Wrocław was not much different ${ }^{1}$ : modernist architecture and major architectural designs, including the Centennial Hall built in 1913, began to flourish in the city. One factor played a key role in planning the spatial development of Wrocław, namely a town-planning competition for the city development that took place in the years 1921-1922. The purpose of the competition was to try to organize the settlement zone within the city and to establish a spatial development framework. The author of the winning project, a German architect and town planner Ernst May acting in cooperation with Herbert Boehm, assumed a strategic approach to shaping downtown Wrocław (i.e. the central part or main business and commercial area of the city) and the space around it. According to the project called Trabanten ("satellites" in German), the city was to be decentralized, meaning that the urbanized central city zone would be surrounded by self-sufficient satellite housing estates. Such housing estates would have good communications and the boundaries between them would be fixed along urban greenery. Furthermore, spatial programme with clearly specified demographic capacity were also provided (see: Figure 1). May's concept was pioneering as at the beginning of the $20^{\text {th }}$ century; it was re-framed in later years covering a larger territory allowing Wrocław to develop [Kononowicz 2010].
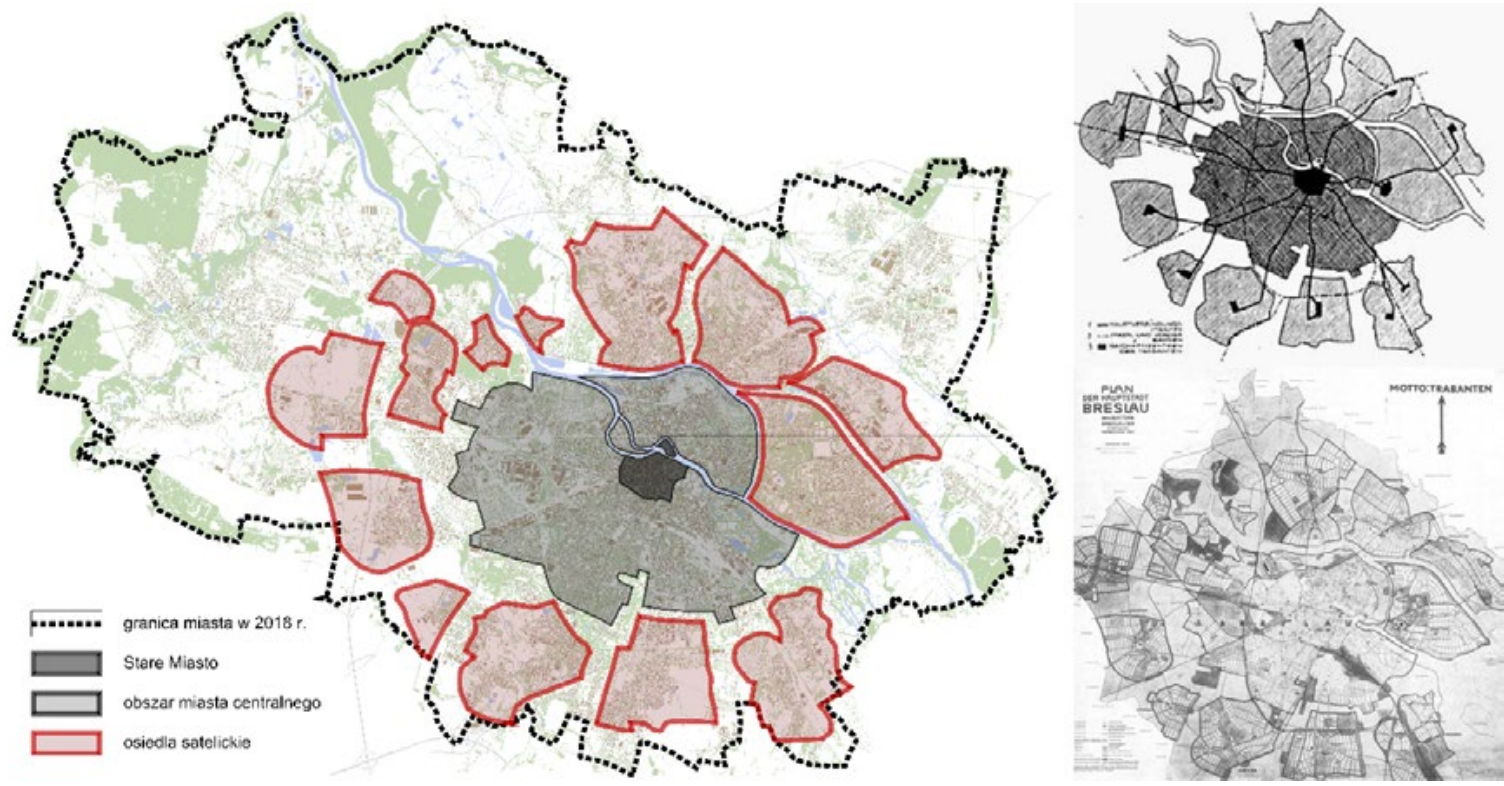

Fig. 1. The concept of satellite settlements around the central area of Wrocław - based on www.kompozytorzy-przestrzeni. blogspot.com

Koncepcja osiedli satelickich wokół obszaru centralnego Wrocławia - opracowanie własne na podstawie www.kompozytorzy-przestrzeni.blogspot.com

Setting clear framework for spatial development of Wrocław based on settlements satellite towards the central zone could have a considerable impact on current functional and spatial structure of the city. Nevertheless, Ernst May's design was not executed, and the city urbanization was closely correlated with transport system and urban green space. At that time, public transport also developed. In the years 1925-1929, the company known as Wrocławskie Tramwaje Miejskie (Städtische Straßenbahn Breslau in German) extended the tramway system and purchased approx. 230 modern - at that time - cars, designed for the needs of Wrocław [Kołodziejczyk 2016]. Spatial development of the city is illustrated by a remarkable plan of Wrocław from 1934 (Plan der Haupstadt Breslau in German) that showed road corridors, railway network, basic elements of natural environment and the expansion of buildings in the capital of Lower Silesia at the beginning of the $20^{\text {th }}$ century. 
The plan also showed buffer strips successively planted alongside five rivers running within administrative boundaries of the city, including elements of greenery (partly in the form of cemeteries and recreation areas) in the vicinity of today's ul. Ślężna and other forms of urban green space within the so-called Krzycka Promenade $^{2}$ along the railway embankment in the south of Wrocław (Figure 2).

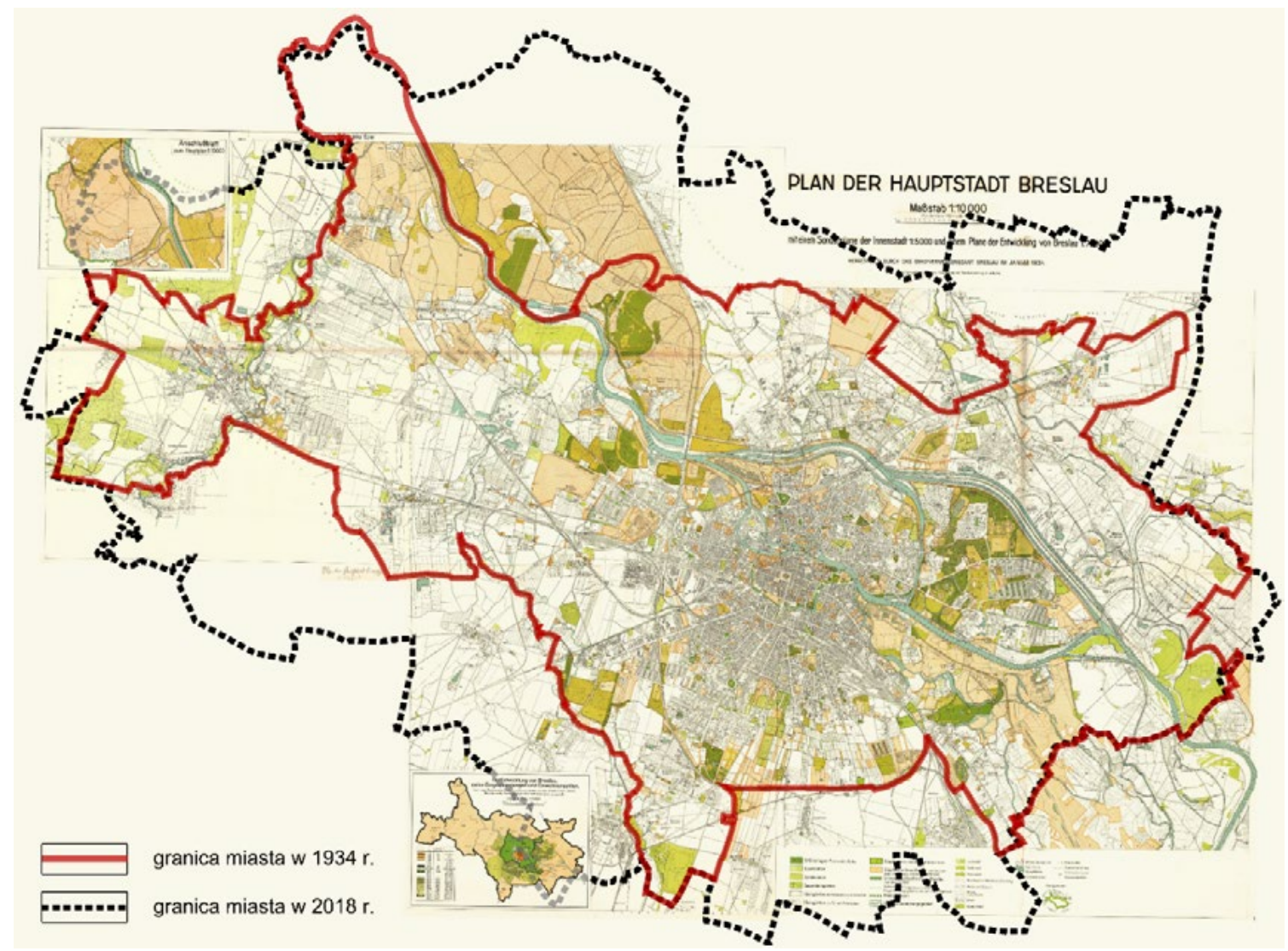

Fig. 2. Borders of Wrocław in 1934 (red line) and in 2018 (black dots) based on the city plan from 1934 Granice Wrocławia w 1934 r. i 2018 r. - opracowanie własne na podstawie planu miasta z 1934 r.

\section{$1945 / 1960$}

Wrocław, the Third Reich city during the Second World War, suffered substantial war damage. The buildings and transport system were destroyed in about $70 \%$ during the city siege, which was an important planning and sanitary problem as the Poles, flocking to Wrocław, could live in only $30 \%$ of the remaining and usable houses (Fig. 3).

The city planners and authorities at that time had to decide whether to rebuild the structure of Wrocław from 1939 or transform it into much needed residential areas. An answer to the above-mentioned issues was to be found in the Initial Concept of Wrocław Development from 1946, developed in the newly-created unit, namely the Wrocław Plan Bureau (Biuro Planu Wrocławia), which reported to the Regional Directorate of Spatial Planning. It was finally decided to keep the identity of the existing space and building substance and introduce some necessary changes to allow Wrocław to further develop and retain historical continuity. The need to create a radial-perimeter transport system and the extension of the radial-ring urban green space were indicated [Przyłęcka 2006]. An additional background to the development of the then planning studies was the Decree 
of April 2, 1946 on planned spatial development of the country, where it was stated (Article 1) that all public and private actions involving the use of land and population distribution should be adapted to the provisions of spatial development plans, which were divided into national, regional and local levels.
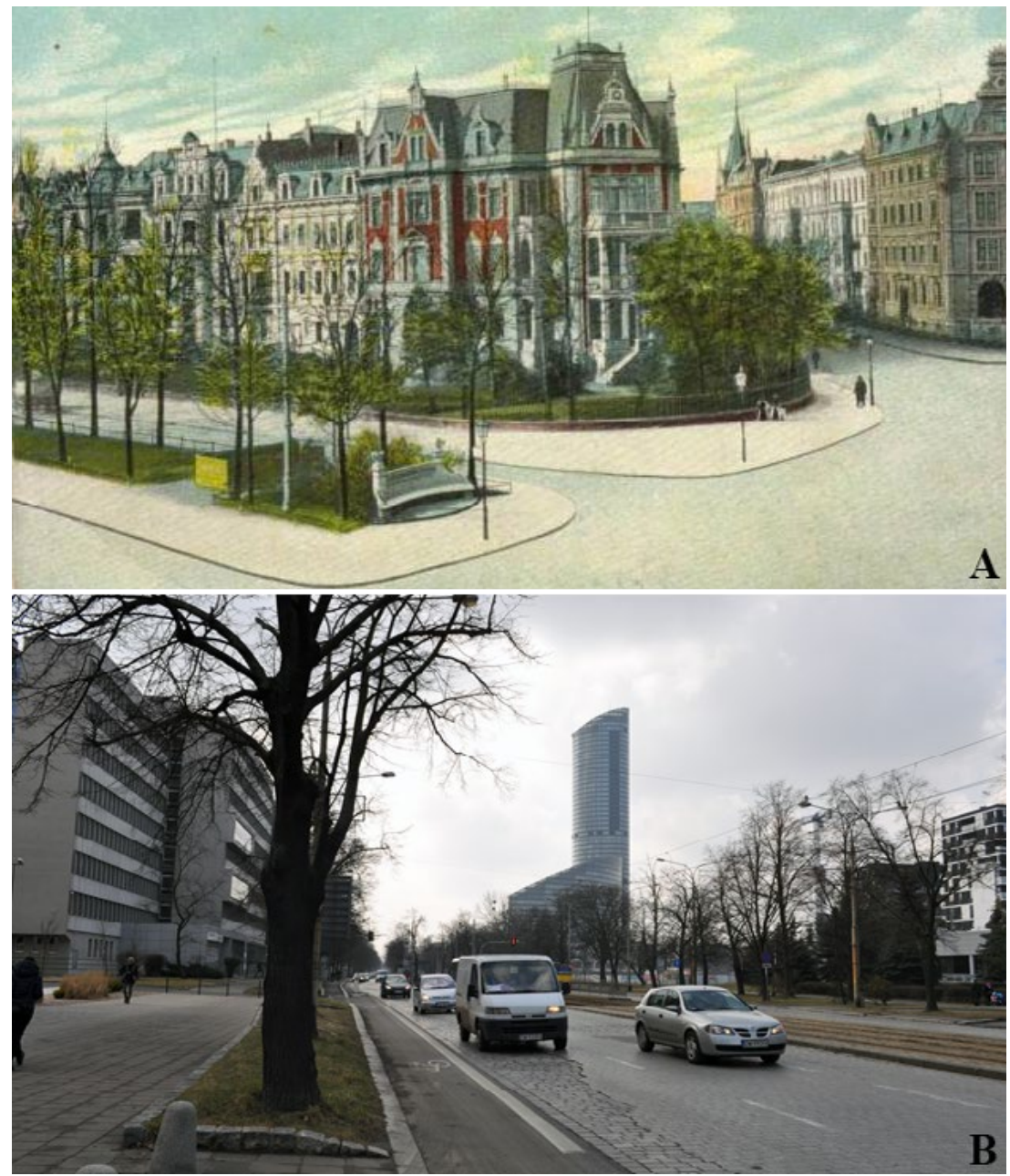

Fig. 3. Change in the image of the southern part of Wrocław in 1900 (A) and 2018 (B), and high-rise building in a place of tenement houses - based on fotopolska.eu (A) and the author's own photograph (B)

Zmiana wizerunku południowej części Wrocławia w latach 1900 (A) i 2018 (B), budynek wysokościowy w miejscu zabudowy kamienicowej - opracowanie własne na podstawie (A) - fotopolska.eu (B) - fotografia autora.

The Initial Concept of Wrocław Development was further elaborated as the General Zoning Plan of Wrocław, first developed in 1946 under the direction of Tadeusz Ptaszycki, and approved in 1949. The draft plan assumed the possibility of spatial expansion around the historical centre of Wrocław in order to reduce the number of people per building in Downtown. A radial-perimeter transport system was introduced and buffer strips were arranged to improve the quality of climate, including those alongside the banks of the Oder, Bystrzyca and Ślęza Rivers (Figure 4).

The General Zoning Plan of Wrocław was developed along with functional and spatial layout of the city connected with the Exhibition of the Recovered Territories organized in 1948. To this end, the City Activation Plan ("Plan Aktywizacji Miasta") was drawn up, pointing to the perimeter building development around selected communications routes and urban green space to be restored. The buildings mention therein were cleared of rubble and secured, the façades were renovated, and new green spaces were created [Przyłęcka 2006]. Both plans, i.e. the General Zoning Plan of Wrocław and the City Activation Plan, resulted in a development of a central hierarchical layout with a dominant historical centre (the Old Town) and a supporting specialist centre in the east of the city as part of areas intended for the Exhibition of the Recovered Territories and the vicinity of the Grunwaldzki Square. 


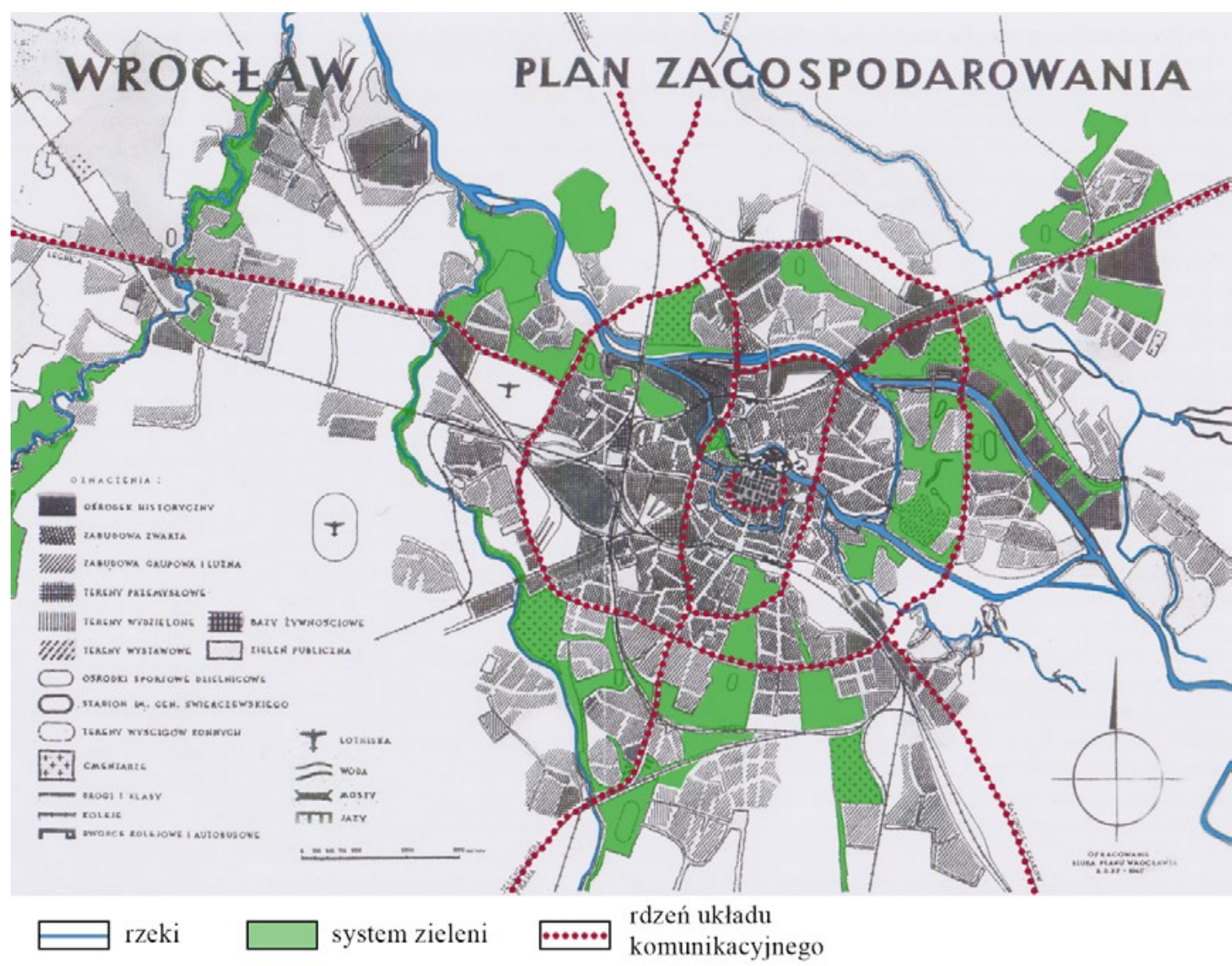

Fig. 4. The General Zoning Plan of Wrocław from 1949; see: Przyłęcka D., 2006, Odbudowa i rozwój Wrocławia w planach zagospodarowania przestrzennego z lat 1945-1994, Agencja Wydawniczo-Poligraficzna RUBIKON, Wrocław.

Generalny Plan Zagospodarowania Wrocławia z 1949 r. - opracowanie własne na podstawie Generalnego Planu Zagospodarowania Wrocławia [w:] Przyłęcka D., 2006, Odbudowa i rozwój Wrocławia w planach zagospodarowania przestrzennego z lat 1945-1994, Agencja Wydawniczo-Poligraficzna RUBIKON, Wrocław.

Later, the central planning trend growing in the country changed local organizational structures in Wrocław. The Wrocław Plan Bureau was closed in favour of the "Cityproject" ("Miastoprojekt" in Polish) established in 1952, which dealt with planning and spatial development issues. The"Cityproject" continued previous planning projects, and as a result, the concept of the Wroclaw development plan for 1970 was framed. The concept was based on the idea of peripheral transport system and other routes forming the city transport core with minor modifications regarding transport corridor towards Poznań. In addition, from the late 1940s the tram network was gradually expanded; however, investment plans related to public transport system were not an integral part of spatial development plans, although they were taken into account at the design stages.

The process of centralization in Poland contributed to the formation of a central Committee for Urban Planning and Architecture ("Komitet ds. Urbanistyki i Architektury" in Polish), and the Architectural and Building Board ("Zarząd Architektoniczno-Budowlany in Wrocław") led by Leszek Dąbrowski as the Main Architect of Wrocław. In 1955, the Town Planning Office ("Miejska Pracownia Urbanistyczna" in Polish) was opened under the direction of Alojzy Kulicz and Zbigniew Bodak as deputy. The General Zoning Plan of Wrocław was prepared in the City Urban Planning Office (Figure 5), which was the first such plan in Poland to be approved by central authorities. It consisted of two complementary studies: the Plan for the City Future Development until 1975 and the Staged Plan for the years 1956-1960. 


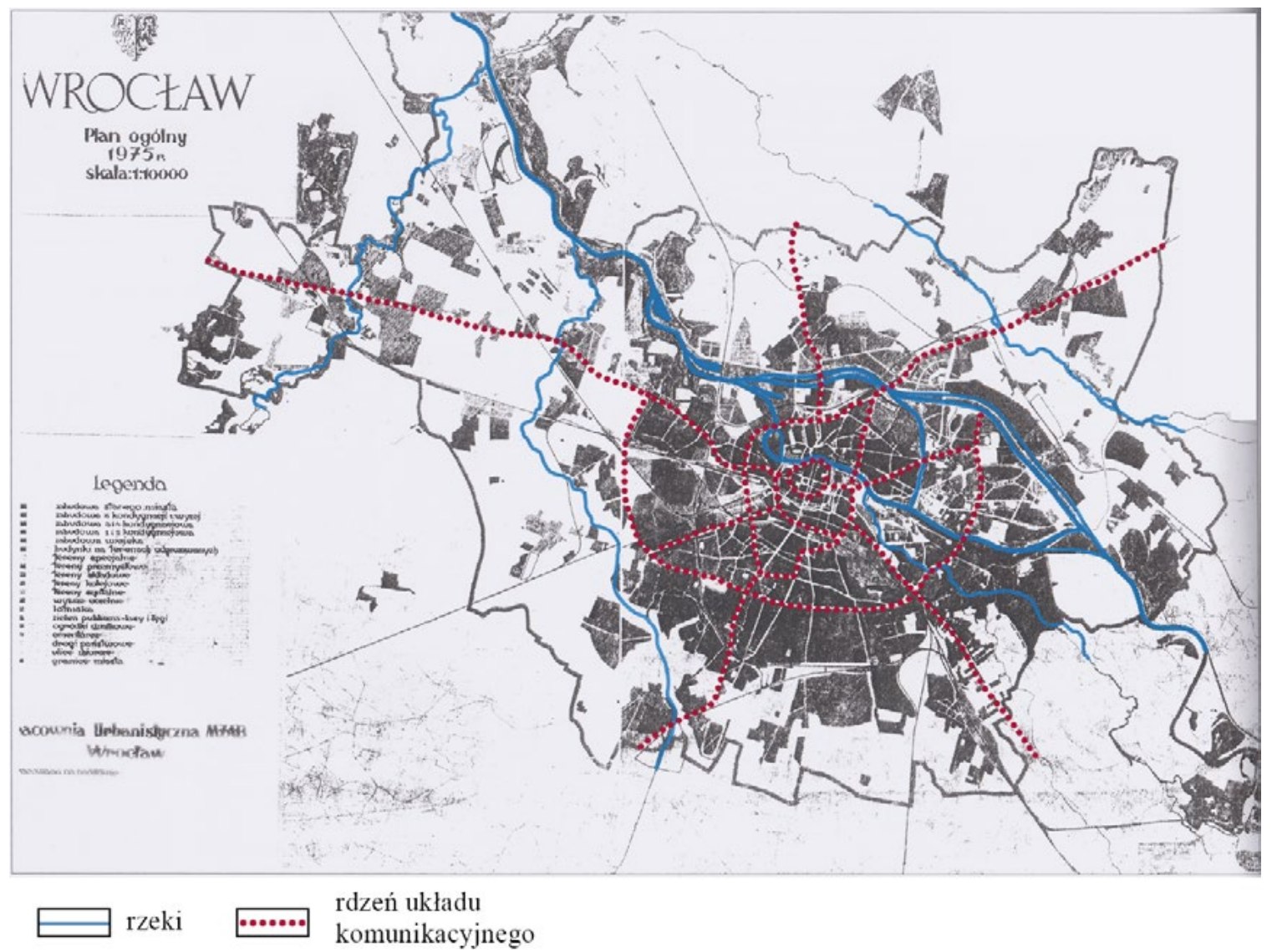

Fig. 5. General Zoning Plan of Wrocław. Perspective to 1975. Perspective to 1975. See: Przyłęcka D., 2006, Odbudowa i rozwój Wrocławia w planach zagospodarowania przestrzennego z lat 1945-1994, Agencja Wydawniczo-Poligraficzna RUBIKON, Wrocław.

Plan ogólny Wrocławia. Perspektywa do 1975 r. - opracowanie własne na podstawie Planu ogólnego Wrocławia. Perspektywa do 1975. [w:] Przyłęcka D., 2006, Odbudowa i rozwój Wrocławia w planach zagospodarowania przestrzennego z lat 1945-1994, Agencja Wydawniczo-Poligraficzna RUBIKON, Wrocław.

The General Zoning Plan of Wrocław with the perspective to1975 limited transport development, and the principles of mobility policy applied in particular to the modernization of current communications routes. The need to build transport system in radial-peripheral shape was still pointed out, but in a slightly different territorial arrangement compared to previous planning studies. Contrary to previous plans, the Downtown Ring Road of Wrocław was not closed. What was, however, similar to former concepts, was the reference to a homogeneous hierarchical layout based on a centrally located Old Town of Wrocław surrounded by urban areas. According to a later update (of 1958) of the General Plan with the perspective to 1980, the city was divided into service centres at basic, community and district level; additionally, a service central site (to be extended to the areas of the Southern Centre and the so-called Kościuszko Residential District) was defined. It was the first clear division of the city into hierarchical centres competent to provide various services to residents. In addition, due to the introduction of the national plan of trunk roads and motorways, the draft plan contained a more detailed range of national main roads as well as regional and local roads.

\section{$1961-1993$}

At the beginning of 1961 legislative changes in spatial planning were introduced because on January 31 of that year, the Spatial Planning Act came into force. Pursuant to Article 1 of this Act, the purpose of spatial planning 
is to (i) ensure proper development of individual areas of the country, including their mutual connections and national interests, and (ii) establish correct spatial correlations between production and service facilities in these areas, thus creating conditions for production development, fulfilment of population needs and protection of natural resources and natural environment. Since the mid-1950s and early 1960 s Poland began to move away from socialist realism, and therefore more freedom and modernity aspirations were allowed (but not on such a large scale as in western Europe, behind the Iron Curtain). This shift also meant the necessity to reserve land for industrial development, which was in line with the Spatial Planning Act. At the local level, the Act allowed local spatial development plans to be implemented in the form of general plans and detailed plans, but no clear instructions on the scope of local plans were given. In the end, such competence was laid on the Chairman of the Committee for Building, Urban Planning and Architecture in agreement with the Chairman of the Committee for Planning operating by the Council of Ministers (Article 28).

After the Act came into force, it was decided that the General Zoning Plan of Wrocław would be periodically updated, but first an initial concept of the city transport system was developed. It was later incorporated into the perspective draft plan to1980 but ultimately it was not adopted. It was recommended to conduct additional studies on functional and spatial structure of the city, which resulted in the adoption of the plan in the later period with the perspective to 1985, herein later referred to [Medeksza 2013].

In the meantime, attempts were also made to re-analyse the possibilities of spatial development of Wrocław, which could form the basis for further planning documents. To this end, Włodzimierz Szostek and Barbara Strzelichowska performed an analysis of Wroclaw development potential, including alternative development concepts. The city already had the General Zoning Plan with its updates providing general principles of spatial policy. Therefore, the Town Planning Office formed District Teams for Town Planning responsible for drawing up more detailed plans. The District Teams for Town Planning prepared many detailed plans for various areas of the city - dedicated to the restoration of downtown buildings and to new projects aimed at developing districts in Wrocław [Przyłęcka 2006].

On the one hand, the search for detailed spatial solutions in different districts of Wrocław resulted in town planners' greater awareness of individual districts, and on the other hand it made the development of the general plan with a perspective to 1985 easier. In the end, the plan was formulated under the direction of Kazimierz Bieńkowski (Figure 6), who worked on it since 1973.

The plan defined the transport system. According to the ideas adopted in the late 1940s, the radial-perimeter shape was made more precise. The Wrocław Downtown Ring Road was not closed from the north, but a longitudinal road was planned in the west of the city; its substantial part coincides with the route of today's Wrocław Motorway Ring Road. The plan also provided for current A4 motorway route in the south and transport system expansion by an additional road in the west, parallel to previously planned road towards Legnica. It should be pointed out that previous general assumptions became an integral part of the draft plan, and the transport structure layout was clarified. As for transport and functional and spatial structure, the plan assumed the closing of the airport in Gądów, which would release lands assigned for residential development with higher parameters of building height. Such a solution was favoured by additional, latitudinal street in the west.

In the General Zoning Plan of Wrocław with the perspective to 1985 , an emphasis was put on systemic development of urban green spaces. The idea of 1949 was continued and developed. A buffer strip in the south was approved, others (a buffer strip in the east of the city and areas alongside the banks of the Oder, Bystrzyca, Ślęza and Widawa River) were enlarged; the Oder Islands ("Wyspy Odrzańskie") were still supposed to be "green lungs" for highly urbanized city centre, and buffer strips alongside the Oder River were widened for areas of building development potential in the west of the city, thus creating the Western Park ("Park Zachodni"). 


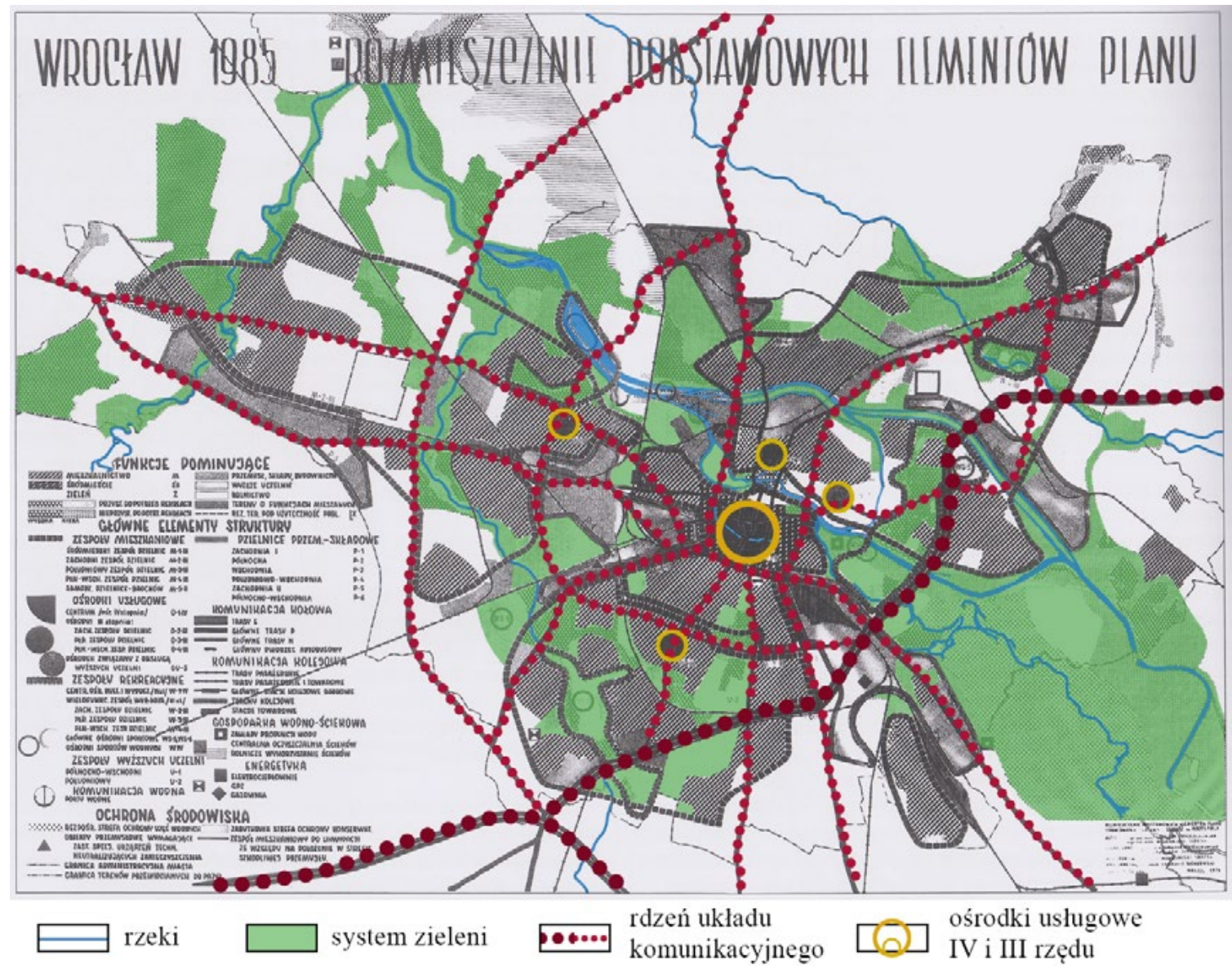

Fig. 6. General Zoning Plan of Wrocław. Perspective to 1985. See: Przyłęcka D., 2006, Odbudowa i rozwój Wrocławia w planach zagospodarowania przestrzennego z lat 1945-1994, Agencja Wydawniczo-Poligraficzna RUBIKON, Wrocław.

Plan Ogólny Zagospodarowania Przestrzennego Wrocławia z perspektywą do 1985 r. - opracowanie własne na podstawie Planu Ogólnego Zagospodarowania Przestrzennego Wrocławia z perspektywą do 1985 r. [w:] Przyłęcka D., 2006, Odbudowa i rozwój Wrocławia w planach zagospodarowania przestrzennego z lat 1945-1994, Agencja Wydawniczo-Poligraficzna RUBIKON, Wrocław.

The above elements of spatial development were to favour the 4-rank layout of service centres. The most important of them - in line with previous studies - was the central site in the place of the Old Town along with four third-rank district centres in the vicinity of ul. Legnicka and ul. Na ostatnim groszu, near two squares: Grunwaldzki and Słowiański and in the south at ul. Powstańców Śląskich. The need for lower-rank centres (primary and secondary) was also pointed out.

The next stages of shaping spatial planning in Wrocław were related to the performance of analyses of connecting the central city and neighbouring places by continuously built-up areas as well as analyses of spatial development of individual districts along with preparation of detailed plans. In addition, the last two decades on the $20^{\text {th }}$ century brought the system transformation. Apart from attempts to implement democratic procedures and build free market and civil society, the spatial planning system was also considered. Town planning, which heretofore was an instrument of oppression, was considered equivalent with deliberately restructured planned economy [Kozanecki 2015]. Therefore, various, sometimes extreme, spatial planning models were sought to be implemented into the country's legal system. According to some models, the idea of planning should be dropped as the expression of opposition to and disapproval of previous system, while other concepts favoured local planning at a very detailed level. In accordance with one of more popular approach, the so called regulatory plans were developed. They became popular thanks to two designers from Łódź, namely Zdzisław Lipski and Jakub Wujek. They suggested that very detailed plans be drafted, consisting of extensive 
analyses of current conditions, public spaces, program and functional and spatial structure and the list of public and social services. According to the assumptions, the plans were to include a detailed transport network with the laying of pipes, sewers, power lines, and cross-sections were to define final shape of streets. Additional elements included: design solutions in the form of visualization, architectural forms for buildings, and boundaries between public and private spaces. It was also considered reasonable to establish identity of particular areas at design stage by indicating names of streets and public spaces [Lipski, Wujek 1986]. The proposed assumptions of regulatory plans corresponded to current understanding of operational planning, in which the planning process iwa closely integrated with the investment and construction process.

The debate on the development of Polish spatial planning system was ended by the Act of July 12,1984 on spatial planning. A space management model that finally emerged was similar to the German model. It was decided that general and detailed local spatial development plans would be implemented, and the process of proceeding with these plans was clarified. Elements of social participation, such as the possibility of submitting comments and proposals to plans or making the plans available for review, were introduced. The forms of such participation are continued to this day with slight changes. What is more, the obligatory substantial scope of local plans contained elements that are currently also used in town planning documents at municipal level.

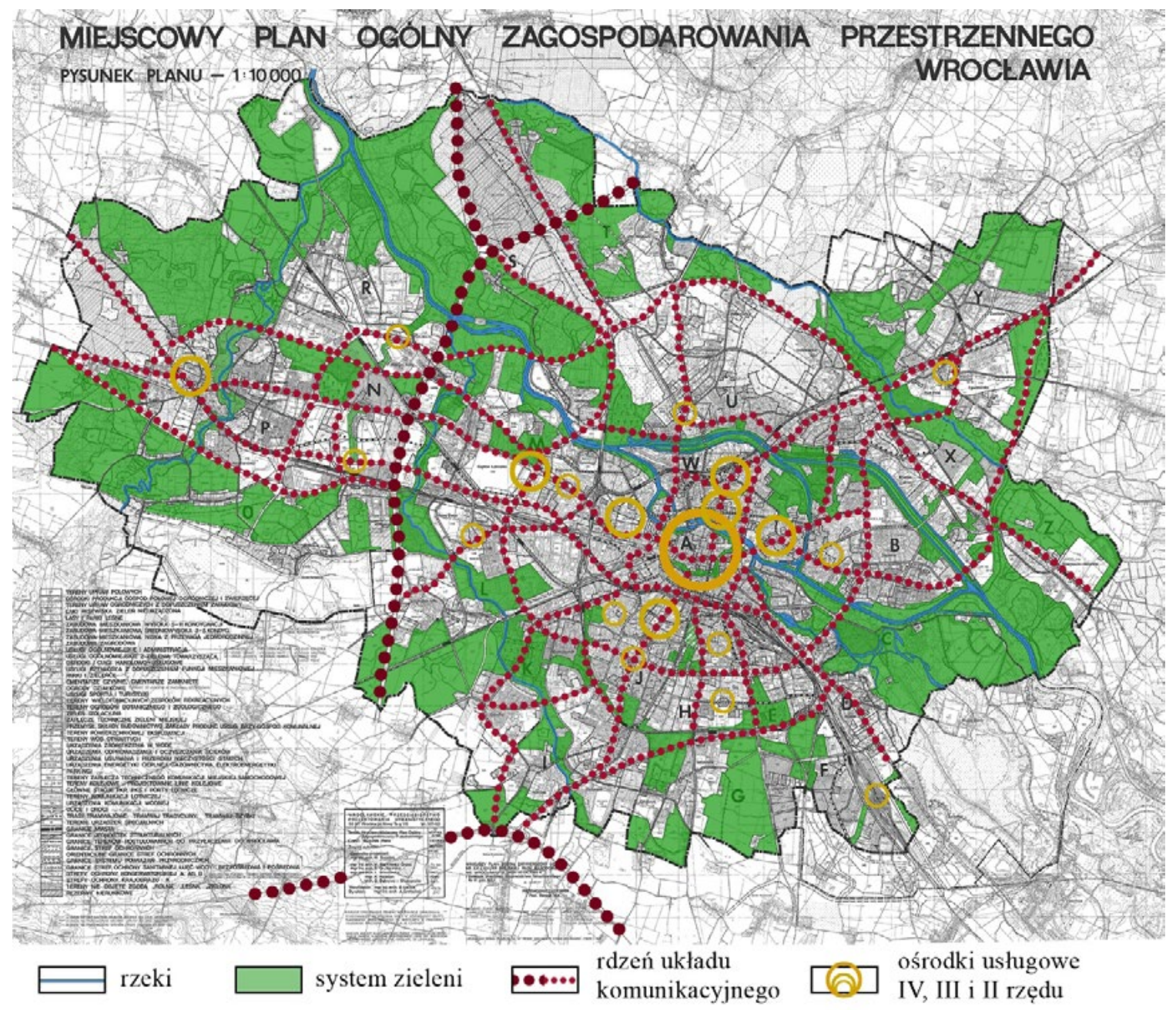

Fig. 7. General Zoning Plan of Wrocław. - based on the City Council Resolution No XXI /104/88 of 10 June 1988.

Miejscowy Plan Ogólny Zagospodarowania Przestrzennego Wrocławia. - opracowanie własne na podstawie Uchwały nr XXI/104/88 Miejskiej Rady Narodowej we Wrocławiu z dnia 10 czerwca 1988 r. 
The first and, at the same time, the last study on town planning creating spatial policy of Wrocław, prepared under the Act of 1984, was the local general spatial development plan of the city of Wrocław adopted by the City Council by Resolution No XXI/104/88 of June 10, 1988 (Figure 7). Pursuant to the Act (Article 10 (1)), before the plan was prepared, variants of spatial development of the city had to be indicated. The plan of 1988 was the first such detailed and comprehensive document dedicated to functional and spatial structure of Wrocław. Compared to previous plans, transport system was expanded; the number of bridges to be built was increased, the concentric-radial arrangement of roads was respected (nevertheless, wherever possible, suggestions were made to expand the roads or upgrade their technical class) and a rectangular arrangement was formed. The idea of a downtown ring road closed from the north was back. The needs for public transport system expansion were addressed. Therefore, communications routes were widened in order to make them more accessible and to make room for lines. The idea of the so-called fast tram was the plan novelty. Its purpose was to connect distant city boroughs through public transport in a quasi-transit form. The planned fast tram line was debatable from today's perspective. Partially, it coincided with the existing lines and no conditions were created for multimodal transport (also known as combined transport) requiring the integration of railway stations and tram stops. Additionally, the plan stipulated motorway ring road towards Warsaw and Poznań, which were built connection with the public road construction for the 2012 UEFA European Championship.

The plan also addressed the issue of green spaces, which is in line with the assumptions of previous planning studies. Greenery included meadows, pastures, forests and tree-covered areas, parks, farmlands, orchards as well as areas of low-intensity development such as gardens, cemeteries and sports grounds. Territorial distribution of the above areas covered river valleys and areas previously considered significant for urban microclimate. The biggest difference compared to previous plans was the southern buffer strip where high-capacity building development was allowed. Nevertheless, due to the occurrence of historical relics (e.g. cemeteries), no construction projects were executed in the area in question.

High accuracy of the plan and the division of the city into smaller structural units favoured hierarchical arrangement of service centres. The plan stipulated spatial accessibility to various service centres within 24 separate structural units and the provision of lower-rank services to residents in more than 100 urban areas. To this end, service centres were divided into four ranks. Hierarchically, the most important centre was the citywide service centre of $4^{\text {th }}$ rank, covering the Old Town. The third-rank service centres included (i) business centre in the Southern Centre ("Centrum Południowe") with surrounding high-rise buildings, (ii) academic centre at PI. Grunwaldzki and Oś Grunwaldzka covering various types of services, (iii) three centres in the west of the city (in the vicinity of important transport nodes or intensified development areas) and (iv) two centres in the north of the city. It was the first such an accurate approach to comprehensive creation of hierarchical structures of services in Wrocław that - on the one hand - were to be provided to a wide range of residents, while on the other hand - they supported the expansion of the city transport structure.

\section{$1994-2002$}

The General Zoning Plan of Wrocław of 1988 is considered by some of the Wrocław town planners as one of the last "rolling" (continuous) plans, i.e. plans that stipulate the city structure preservation, continuation and improvement. Such understanding of design was affected by later structural and organizational changes that led to the closing of the Town Planning Office and removal of the Wrocław Urban Design Company from executing urban projects in Wrocław. Thus, the town planning continuity that began in 1955 was broken. This problem was solved by the establishment of a new Municipal Office unit, namely Wrocław Development Office in 1996, which directly resulted from the study on land use planning developed by Tadeusz Zipser's team [Przyłęcka 2006].

The plan reflected a new legal situation in Poland. A new Act of 7 July 1994 on spatial planning was introduced. Studies on land use planning, as acts that shaped municipal spatial policy and replaced general plans, ceased to be the acts of local law and could not form the basis for issuing zoning decisions (Article 6 (7)). The new Act reduced the importance comprehensive town planning analyses within municipal boundaries and de facto introduced the requirement to implement local spatial development plans to protect lands from unfavourable investment projects. Pursuant to the Act, municipal councils were no longer required to adopt draft layouts. 
The plan was adopted in 1998 (Figure 8). The idea of a radial-perimeter shape of transport system was continued. Compared to the plan of 1988, the route of the Wrocław Motorway Ring Road (along with the variant of the route of one part of the ring road) and the northern part of the Wrocław Downtown Ring were corrected. In connection with the idea of functional and spatial structure of the city, attempts were made to change transport system in a manner improving communications between areas of economic activity and housing. In the above context, the biggest difference in the routes can be seen in the so-called Axis of Incubation ("Oś Inkubacji"), which was not emphasized in the previous plan to the same extent. Its task was to integrate economic activity in the western and southern parts of the city, and facilitate access to air transport and roads of higher technical classes. An additional road connection towards Poznań was abandoned. Moreover, the plan revealed a tendency to minimize the number of roads of higher technical classes in favour of local roads leading to housing estates. The idea of fast tram that emerged in 1988 was rejected.

Transport system was to favour the city hierarchical structure. A division into the central site and cooperating centres was made, thus creating the metropolitan centre of Wrocław. In order to develop the polycentric structure and relieve downtown Wrocław of some functions, two additional, yet equivalent, centres of general and regional importance were introduced, namely the West Pole and the South Pole. The service centres were supported by district and local centres providing all kinds of services to the residents. Thus presented structure of service centres corresponded to hierarchical division into $1^{\text {st }}$ to $4^{\text {th }}$-rank centres; however, indirect elements were also introduced, i.e. buffer centres located nearby the city administrative boundaries.

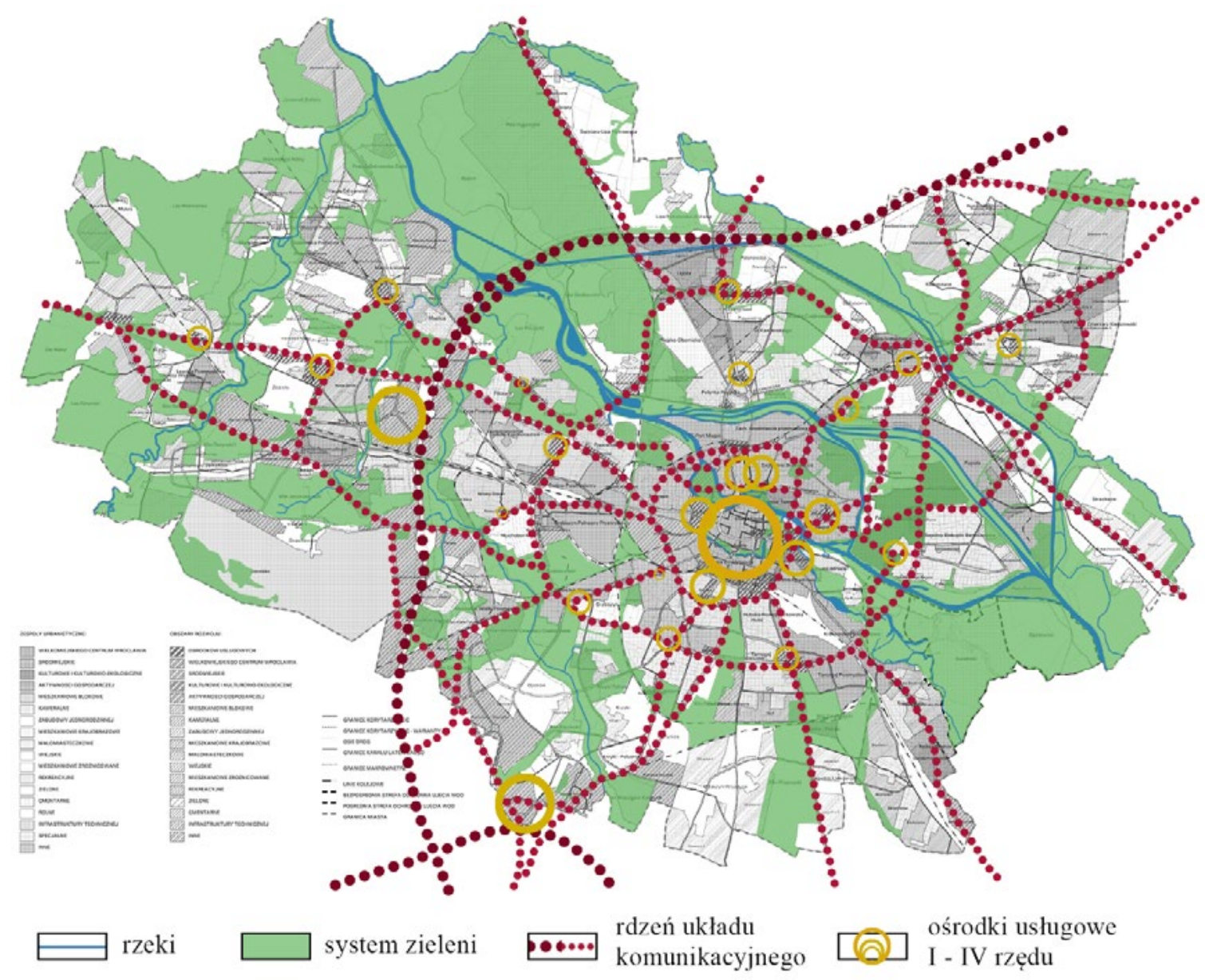

Fig. 8. Study on land use planning of the Wrocław municipality of 1998 - based on Resolution No XLVIII/680/98 of the City Council of Wrocław of January 30, 1998.

Studium uwarunkowań i kierunków zagospodarowania przestrzennego gminy Wrocław z 1998 r. - opracowanie własne na podstawie Uchwały nr XLVIII/680/98 Rady Miejskiej Wrocławia z dnia 30 stycznia 1998 r. 
Urban greenery did not significantly change, either: an extensive hydrographic layout together with surrounding areas remained its core. The southern buffer strip, same areas adjacent to the Widawa River and the northern greenery were widened as irrigation fields. In order to build a coherent structure, additional passages between individual buffer strips were also introduced, yet often quite symbolically. The area of green spaces in the north-eastern part of the city was reduced by newly built housing estate yet a green corridor was kept.

In 2001, based on Resolution No XXXV/1126/01, the Wrocław City Council introduced an amendment to the study on land use planning of the Wrocław municipality, however basic elements analysed in this paper were not changed. In the revision of the study, the principles of shaping industrial areas, health and education centres were slightly changed.

The study on land use planning of 1998 initiated the process of systemic and detailed shaping of the space of Wroclaw. At that time, a team from theWrocław University of Technology and Science under the direction of Tadeusz Zipser developed methods for forecasting settlement processes and supporting planning decisions, including the ORION simulation and decision model [cf. Brzuchowska et al. 1994]. These methods are still an important source of information about urban space.

\section{After 2003}

Both organizational and socio-economic reforms in Poland proved the need to amend the act on spatial development. On March 27, 2003, the Sejm adopted the Act on spatial planning and development, which, despite the nearly 50 amendments, is still valid today. The initiated legislative changes, despite significant similarities to the Act of 1994, still raised questions about the need for planning in the free market economy. The arguments for planning were as follows:

an attempt to protect local society interest against the enrichment of individuals at the costs of others, i.e. protection against simplified understanding of private property,

- an attempt to eliminate functional and spatial conflicts and to curb the society polarisation.

Thus presented arguments require a departure from restrictive planning in favour of stimulative planning, in which no significant functions and forms of development are indicated, but rather rules and principles of land use are established [Pracowani ... 1995]. On the one hand, the Act provides for the possibility of taking town planning actions to stimulate development through spatial planning, while on the other hand it allows competent authorities to issue administrative decisions regarding the location of investment projects of public purpose and zoning decisions that do not have to be consistent with spatial policy principles formulated in the studies on land use planning. Pursuant to the Act, investment project could be executed based on administrative decisions which did not have to be consistent with municipal studies on land use planning. 15 years after the Act became effective it is obvious that both in Wrocław and in other Polish cities many investment projects were executed contrary to municipal spatial policy and are believed to have degraded public space.

The amendment to the Act and new needs of spatial policy of Wrocław resulted in changing the study on land use planning (Figure 9). The study was amended pursuant to the provisions of the Act of 2003, which did not differ significantly from the Act of 1994. The amendment was in line with the mandatory scope of the Act, nevertheless methodological achievements and the most important elements of spatial development, defined in the study on land use planning of 1998 [Resolution ... 2006], were used. Previous general assumptions of transport system were changed. Only one variant of the route of the Wrocław Motorway Ring Road was selected while the route in the vicinity of the northern administrative boundries of the city was adjusted. The idea of the Wrocław Downtown Ring Road was continued, but the route in its northern part was modified. There was an additional element of the study on land use was the introduction of the Wrocław Great Ring Road, i.e. another ring road running further from the centre than the Wrocław Downtown Ring Road, in the south and east. In the west and north it was to integrate with the Wrocław Motorway Ring Road. Even though a significant section of the ring road run outside administrative boundaries of Wrocław, the study on land use planning of 2006 as amended was the first document to show it as an additional information sign.

The greenery area was significantly reduced. The area of urban green space decreased compared to 1998. However, the basic elements (i.e. five rivers flowing through Wrocław), which have been considered since the 
1950s, can still be spotted. The biologically active areas in the southern buffer strip (the Ślęza River) were reduced, so was the area for irrigation fields in the vicinity of the Oder River and in the Mokrzański Forest, where a housing estate called "Osiedle Malownicze" was built since 2005.

A four-level arrangement of service centres with minor modifications in their location was also preserved. The basic structure did not change: a metropolitan area with a multifunctional downtown and several supporting centres (e.g. two multifunctional centres). District centres (which were considerably modified as to their location) and specialized commercial centres were also established.

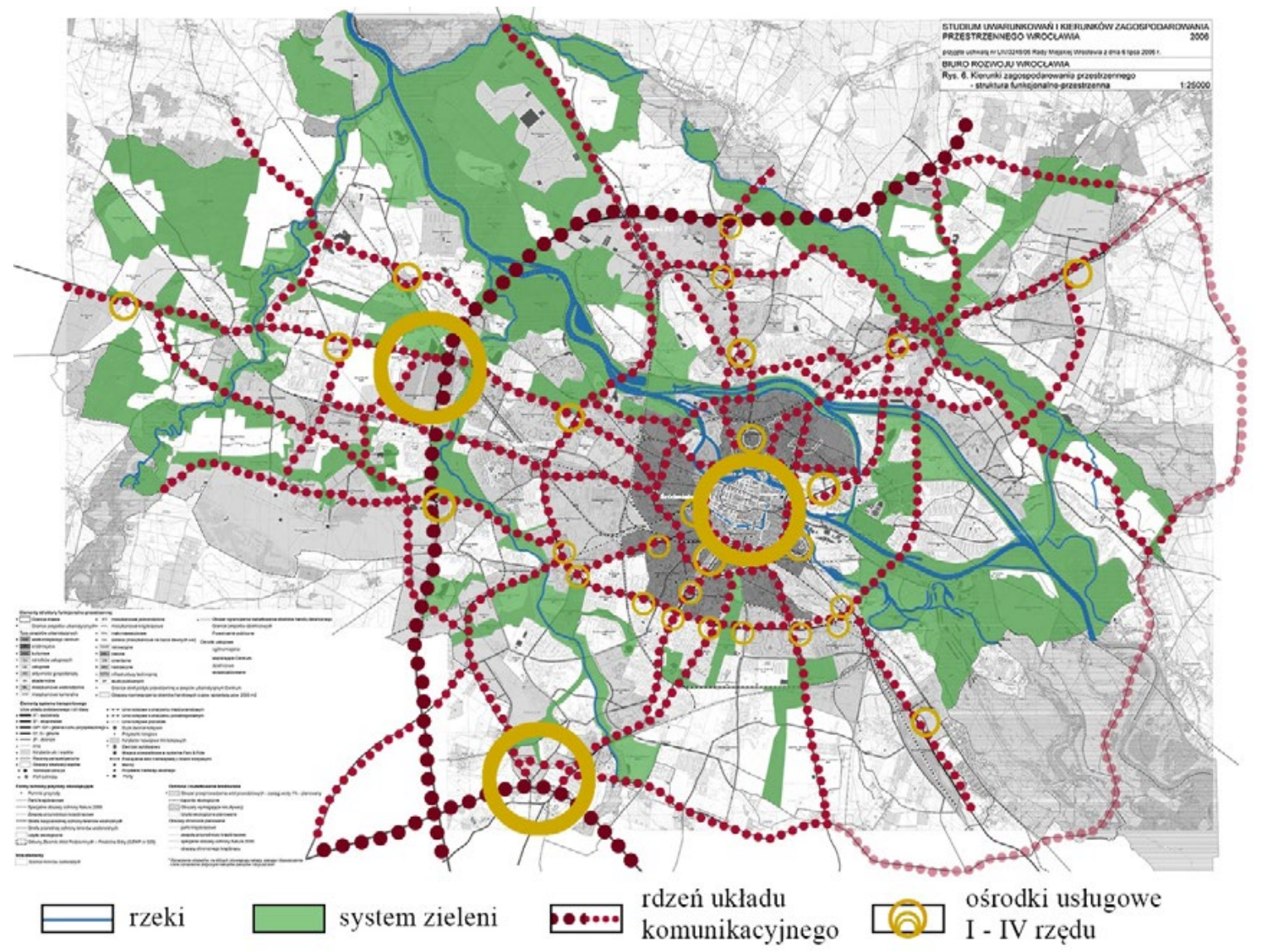

Fig. 9. Study on land use planning of 2006 - based on Resolution No LIV/3249/06 of the City Council of Wrocław of July 6, 2006. Studium uwarunkowań i kierunków zagospodarowania przestrzennego Wrocławia z 2006 r. - opracowanie własne na podstawie Uchwały nr LIV/3249/06 Rady Miejskiej Wrocławia z dnia 6 lipca 2006 r.

Two years after the study on land use planning was in force, changes were made to it (Figure 10). As the authors say, the essence of current amendment is the introduction of small adjustments and additions to the city spatial policy resulting mainly from new documents and analyses performed for Wroctaw, changes in technical solutions in urban infrastructure and the emergence of new problems that have to be solved [Resolution ... 2010, p. 12]. The city transport system was not changed: only a small correction was made in the route of the road to Oborniki Śląskie and the so-called Incubation Axis; several adjustments were made to urban greenery: it was enlarged by same areas near irrigation fields and an additional buffer strip in the south of the city, near railway tracks on the route to Strzelin. As regards the hierarchy of service centres, only one modification was introduced, namely the so-called Science and Innovation Pole ("Biegun nauki i innowacji") was added to the Innovation Park in Pracze Odrzańskie (currently Polish Centre for Technology Development). 


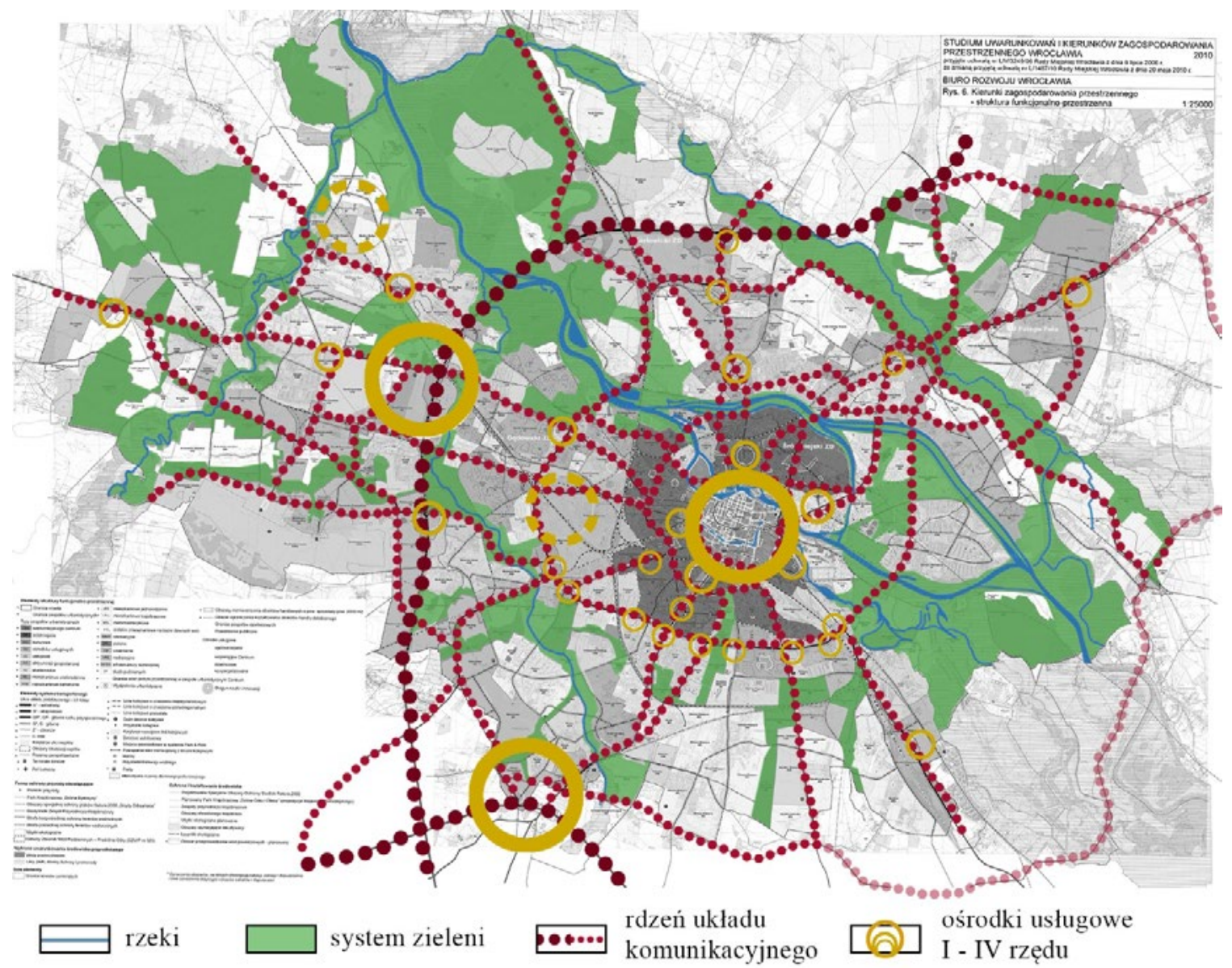

Fig. 10. Change in the study on land use planning of Wrocław of 2010 - based on Resolution No L/1467/10 of the City Council of Wrocław of May 20, 2010.

Zmiana studium uwarunkowań i kierunków zagospodarowania przestrzennego Wrocławia z 2010 r. - opracowanie własne na podstawie Uchwały nr L/1467/10 Rady Miejskiej Wrocławia z dnia 20 maja 2010 r.

The study on land use planning of 2010 was in force for 8 years. In 2018 the Wrocław City Council, by way of Resolution No L/1177/18 of January, 11 2018, adopted another one (Figure 11). The study was a response to multiple amendments to the Act on spatial planning and development, changes in the city functional and spatial conditions and the need to socialize the planning process in the city. Social consultations that lasted over a year, more than 100 working meetings, more than 4,800 applications and more than 1,100 comments influenced the final shape of the document [Studium Wrocław 2018].

The essential elements of the city transport structure were not changed. The route of the road to Oborniki Śląskie was restored to its state of 2006 and the rank of the passage in the vicinity of Kłokoczyce in the north of Wrocław to the Wrocław Motorway Ring Road and trunk road No 98 was raised. Particular attention was devoted to urban greenery ${ }^{3}$. The new study on land use planning is devoted to green space to a large extent. This is one of the priorities and a completely new approach. We assumed that greenery is not complementary to the city structure. It creates the city. That is why we mapped out approx. 1000 hectares of new green areas in the study (compared to the previous one), partly excluding them from housing development, says Anna Sroczyńska, Head of the Wroctaw Development Office. It includes Pola Osobowickie, areas of Nowa Leśnica, Żary, Zgorzelisko, Pawtowice, Swojczyce and Maślice [Studium Wrocław 2018]. Decrease of housing development opportunities 
(and thus enlarging green areas) was also connected with the amendment to the Act on spatial planning and development under the Act on revitalization, which imposed a requirement to analyse municipal needs and development opportunities, and consequently to assess acreage intended for housing development. In spite of the lack of clear statutory guidelines about the principles of such an assessment, the Wrocław town planners determined the target usable floor space per city resident, and indicated the demand for residential acreage based on such usable floor space and demographic forecasts. Ultimately, part of the areas previously intended for residential purposes was incorporated into green space. An additional advantage of the study on land use planning of 2018 is a systematic approach to greenery and climate. Not only the spatial structural core of urban green space, but also green spaces for rest and play as part of other urban areas were marked on the plan. Moreover, the designers clearly noticed the need to analyse the directions of airflow in Wrockaw, and consequently the need to build residential estate in a manner that is based on the analysis results.

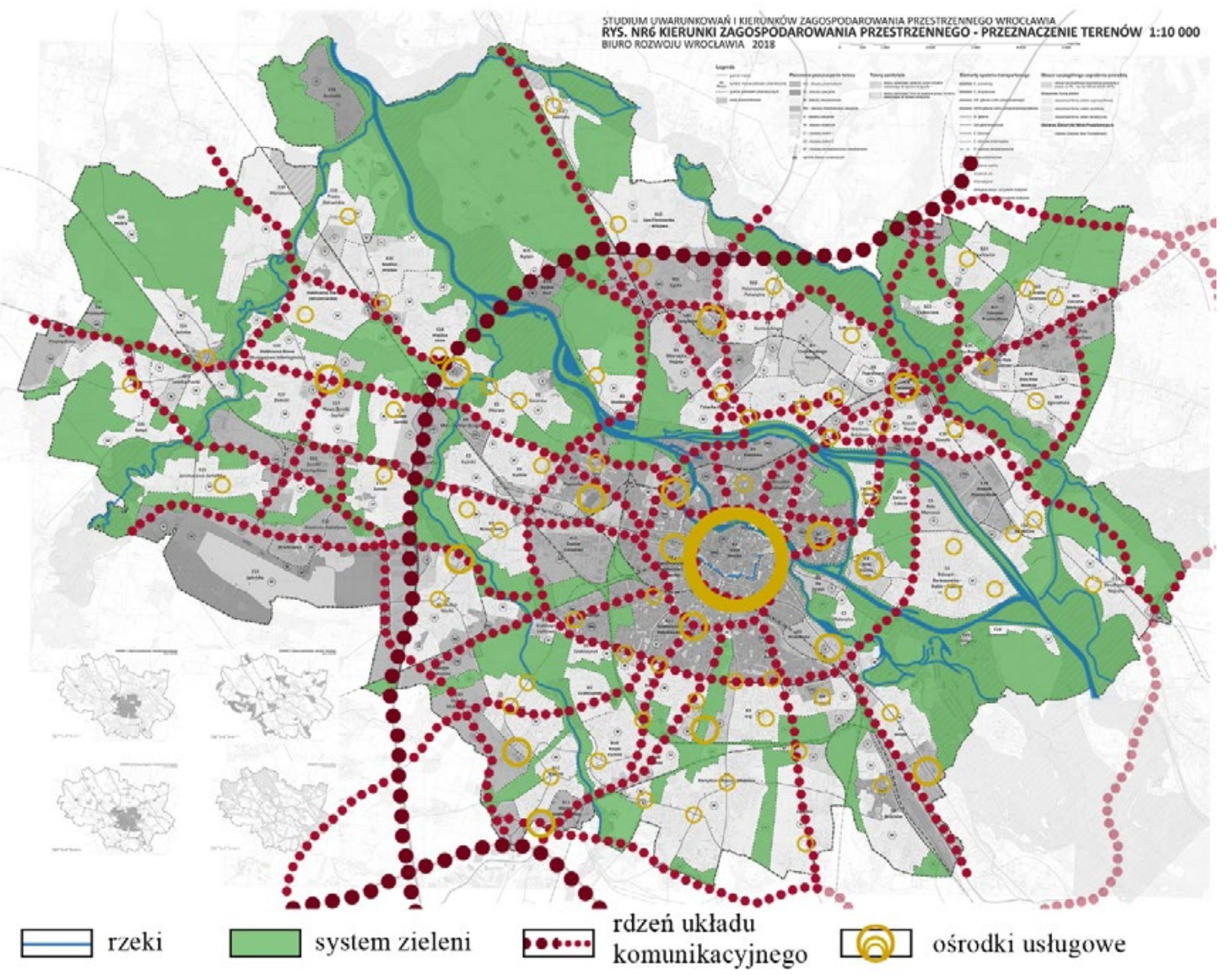

Fig. 11. The study on land use planning of 2018 - based on Resolution No L/1177/18 of the City Council of Wrocław of January 11, 2018.

Studium uwarunkowań i kierunków zagospodarowania przestrzennego Wrocławia z 2018 r. - opracowanie własne na podstawie Uchwały nr L/1177/18 Rady Miejskiej Wrocławia z dnia 11 stycznia 2018 r.

In the latest study on the land use planning for Wrocław, an emphasis was put on a different way of shaping service centres than before. Local centres play the leading role: their functional and spatial offer must meet the residents' expectations and address their daily needs. Such centres are followed by another element of hierarchical structure of services, namely specialized centres that offer wide range of services specific as to their scope, industry, price level or nature [Resolution ... 2010, p. 133]. The Centennial Hall, the Zoo or the Municipal Stadium are perfect examples of such specialized centres. The central site is located within the Old Town, but 
its expansion should cover PI. Społeczny, ul. Powstańców Śląskich, an area around the railway station at pl. Świebodzki, pl. Jana Pawła II and Kępa Mieszczańska. The central site is shaped to increase spatial accessibility through alternative means of transport (compared to individual forms of transport) and improve the quality of public spaces.

\section{Conclusions}

The last 70 years in Poland is a period of dynamic changes, initially systemic and then socio-economic. These changes were followed by town planning, which is an inseparable, spatial element of development. Contrary to preliminary assumptions and opinions of some Wrocław designers referred to herein, it turns out that the Wrocław urban planning and spatial planning are the result of an evolutionary approach to the spatial development issues. The analysed elements of functional and spatial structure appearing in documents affecting spatial policy of Wrocław, i.e. transport system, mobility policy, natural environment with recreation and leisure, and hierarchical arrangement of service centres, result from the adaptation of planning and social needs to the stage of civilization and technological development with consideration of and respect for previously made decisions and historical conditions.

Understandably, there have been changes in the analysed elements of spatial structure of Wrocław over decades. The most important (and still developed) element of the city spatial structure in the analysed time horizon was the radial-perimeter layout of transport system. The most frequently changed element of the city transport system was the northern route of the Wrocław Downtown Ring Road, which was sometimes completely neglected in the projects, and sometimes its route was modified. However, since 2006, one variant of the planned route has been successively maintained. A complete novelty was the marking off the strips of land for the construction of a motorway ring road in the west of the city in 1988; the idea was clarified in later years, and finally the ring road was constructed for the 2012 UEFA European Championship as the Wrocław Motorway Ring Road. There were other innovative ideas referring to development of mobility system, such as a fast tram, which was planned in 1988, but in subsequent planning documents this idea was not continued.

The smallest changes in planning projects concerned green space. The need to integrate greenery into housing zones and areas of economic activity was recognized from the beginning. In each analysed document, the greenery development was based on five rivers flowing through Wrocław. Additional elements were added and were modified over the years, including territorial range of the southern buffer strip and irrigation fields in the north-west of the city. A vital significance was attached to urban greenery in the latest study on land use planning of 2018. Protecting green areas against the effects of anthropopressure results on the one hand from the residents' needs and opinions obtained through social consultations, and on the other hand - from an amendment to the Act on spatial planning and development, which imposed an obligation to assess areas intended for development, and perform analyses of the demand for new residential buildings.

In all planning analyses discussed herein, the historical area of the Old Town - undoubtedly prestigious for the city, the region and the country - was indicated as the basic element of hierarchical arrangement of Wrocław service centres. Nevertheless, in every study on land use planning and in general plan the concepts of the remaining elements of hierarchical arrangement were changed. A lack of consistent spatial policy in this area, and therefore dynamic changes in the approach to shaping service centres, caused territorial diversification in the provision of services to residents by service centres of various rank. The above situation led to an approach presented in the latest study on land use planning, which stipulated the largest number of local centres providing basic services to residents in the vicinity of their places of residence, namely a central centre and a health centre, a leisure centre, a community centre, and s commercial centre. This way of shaping service centres differs from previous suggestion based on four-rank hierarchical structure. The debate on the needs of shaping service centres, their hierarchy and service systems is still taking place in Wrocław. However, the emergence of another large shopping malls that are closed to public space of the city does not create favourable conditions for such debates to be held.

Legislative and economic reforms in Poland since 1989 changed the understanding of spatial planning. Investment projects executed in the spirit of these changes can be assessed as an all-encompassing freedom which in time turned out to be a democratic anarchy [Załuski 2005, p. 80]. In Wrocław, despite amendments 
made to laws related to spatial planning, the continuity in urban planning was maintained, and the diversity can probably be observed on a much larger scale in local plans (and detailed plans), which were not the subject of the paper. However, reducing the importance of planning on considerable scale in the Act of 1994, which is upheld to this day, does raise doubts. The actual usefulness of studies on land use planning of municipalities and cities consists only in establishing spatial policy, which can be completely changed during the process of issuing zoning decisions (which is very difficult to stop), in the form of zoning permits, and decisions on the location of public purpose investments that do not have to be consistent with the adopted studies on land use planning. On the other hand, the so-called "special acts" adopted by central authorities, which only illusionary accelerate investment process at the expense of reducing the importance of regular acts of law, ignore town planning as the art of reasonable continuation ${ }^{4}$.

\section{Reference}

[1] Brzuchowska J., Litwińska E., Ossowicz T., Sławski J., Zipser T., 1994: The simulation-decision ORION Model (in Polish). Oficyna Wydawnicza Politechniki Wrocławskiej, Wrocław.

[2] Decree of April 2, 1946 on planned development of the country.

[3] Kołodziejczyk K., 2016: Transformations of the historic depot of public transport in Wrocław into cultural and tourist facilities (in Polish). Czasopismo Naukowe Turystyka Kulturowa, No 6/16, Poznań, p. 54.

[4] Kononowicz W., 2010: Wrocław achievements of the urbanist and architect Ernst May in 1919-1925 - a stage on the way to functional Frankfurt (in Polish). Kwartalnik Architektury i Urbanistyki: teoria i historia, vol. 55, p. 3.16.

[5] Kozanecki P., 2015: Professor Tadeusz Markowski: they named us urban planners - communist [interview] (in Polish). www.wiadomosci.onet.pl, access 01/10/2018.

[6] Lipski Z., Wujek J., Experience in the design and implementation of large residential estates in Łódź, Poland (in Polish). Czasopismo architektura No 1 (429), Łódź 1986, p. 18.40.

[7] Medeksza Ł., 2013: Town planning is the art of reasonable continuation (in Polish). Kwartalnik "Pamięć i Przyszłość" No 19 (1/13), Wrocław, p. 73.74.

[8] Pracownia Autorska Planu „TEREN”, 1995, Our Plan - Łódź - Our Space (in Polish). Agencja Wydawnicza-Reklamowa BESSO, Łódź, p. 15.

[9] Przyłęcka D., 2006: Reconstruction and development of Wrocław in zoning plans in 1945/1994 (in Polish). Agencja Wydawniczo-Poligraficzna RUBIKON, Wrocław, p. 12.14, 27.33, 53.

[10] Resolution No L/1177/18 of the City Council of Wrocław of January 11, 2018 on the adoption of study on land use planning (in Polish).

[11] Resolution No L/1467/10 of the City Council of Wrocław of May 20, 2010 on the adoption of study on land use planning (in Polish), p. 12, 133.

[12] Resolution No LIV/3249/06 of the City Council of Wrocław of July 6, 2006 on the adoption of an amendment to the study on land use planning (in Polish), p. 8.

[13] Studium Wrocław, 2018: A new studies on land use planning of Wrocław is passed by the councilors (in Polish). www. zaplanuj.wroclaw.pl, access 03/10/2018.

[14] Act of July 7, 994 on spatial development (in Polish).

[15] The Act of July 12, 1984 on town-and-country planning (in Polish).

[16] The Act of March 27, 2003 on spatial planning and development (in Polish).

[17] The Act of January 31, 1961 on town-and-country planning (in Polish).

[18] Załuski D., 2005: Trends in shaping public spaces at the end of the $20^{\text {th }}$ century (in Polish). in: Public space of a post-industrial city, Biblioteka urbanisty No 5, edited by. Kochanowski M., Warszawa, „Urbanista” sp. z o. o., 2005, p. 55.80. 


\section{Wrocławska urbanistyka od planów ogólnych do studiów uwarunkowań i kierunków zagospodarowania przestrzennego}

Streszczenie: Celem niniejszego opracowania jest próba zdiagnozowania stopnia zmian wybranych elementów struktury funkcjonalno-przestrzennej Wrocławia. Opracowanie stanowi przegląd wrocławskiej urbanistyki na przełomie XX i XXI wieku. Analizie poddano plany układu komunikacyjnego, zagadnienia środowiska przyrodniczego, rekreacji i wypoczynku, jak również proponowane układy oraz systemy obsługi mieszkańców. Elementy te zestawiano z krajowymi procesami legislacyjnymi oraz ogólnymi tendencjami w projektowaniu urbanistycznym.

Słowa kluczowe: dokumenty planistyczne, historia planowania przestrzennego, polityka przestrzenna, Wrocław 